\title{
Safety Precuations and Tools Examination for Employees of Power Plant
}

\author{
K. Thiyagarajan, S. Jeni Theresa, T. Subhalatha
}

\begin{abstract}
Employee welfare and safety has been seen as one of an organization's key performance measures. Changes in employees ' working life and changes in both the internal and external business environment have brought tremendous transformation in organizational behaviour. Globalization, innovation and other aspects of work-design compelled companies to focus on the safety and welfare of workers.
\end{abstract}

\section{Keywords: Employee welfare, Globalization, Welfare}

\section{INTRODUCTION}

Organizations must set standards for taking care of the professional and personal interests of the staff. Expanding dependence on innovation, appropriated work game plans, expanding work pace, and assorted variety in the workplace making a few difficulties for staff in Human Resource Management. In the first place, potential new perils rise up out of the presentation of new innovations and in an increasingly virtual association through work execution[1]-[5]. Firstly, corporations are becoming smaller and flatter and redefining the quality of the job and the essence of the relationship between them.

Safety: Safety in the workplace means having an environment free from injury and hazards. Proper processes and procedures will allow employees to work without worrying about the safety.

Labour Welfare: The concept of labour welfare is necessarily dynamic and has been interpretedin different ways from country to country and from time to time and even in the same country, according to social institutions, degree of industrialization and general level of social and economic development. Labor security requires' such utilities, facilities and amenities as sufficient canteens, rest and leisure facilities, sanitary and health facilities, provisions for commuting to and from and for the lodging of workers employed at their homes ' assistance, and such other services[6]-[8].

Revised Manuscript Received on December 11, 2019.

K. Thiyagarajan, Department of Science and Humanities, Bharath Institute of Higher Education and Research, Chennai, India. Email: thiyagu768@gmail.com

S. Jeni Theresa, Department of Science and Humanities, Bharath Institute of Higher Education and Research, Chennai , India. Email: littleflower1812@gmail.com

T. Subhalatha, Department of Science and Humanities, Bharath Institute of Higher Education and Research, Chennai , India. Email: subhalatha.thavasikannan@gmail.com

\section{OBJECTIVES}

1. To recognize the organization's knowledge of safety or relations facilities among the employees.

2. Or find out how employees use healthcare services 3. To determine the level of employee satisfaction with social welfare facilities.

\section{RESEARCH METHODOLOGY}

A sample survey was conducted inside the thermal plant to achieve the study's goals and the responses were collected from the plant's employees. The employees were given a questionnaire and asked to answer questions related to the thermal plant's safety and welfare activities[9]-[12].

\section{A. Sample Size}

A simple sampling method was used to take sample size of 100 employees at the thermal facility. This technique has been adopted because the plant has several workers and a random sampling methodology is difficult to apply.

\section{B. Data Collection}

Via questionnaires, personal interviews and conversations with officials and managers at the power plant, data was collected directly from the respondents[13]-[15]. Employee reactions to the organization's worker's "health and security" interventions were analyzed using relevant statistical tools found in Levin and Rubin (2000).

\section{RESULTS AND DISCUSSION}

The data collected are analyzed using correct statistical tools and the findings were appropriately presented to meet the above-mentioned objectives. 1. To understand the organization's awareness of security and welfare facilities among the employees. The employees were asked to rate their awareness about the facilities provided by the thermalplant and the following gives the details

Table 1: Ratings for Awareness About Facilities

\begin{tabular}{|l|l|l|}
\hline & Frequency & Percent \\
\hline Excellent & 4 & 4.0 \\
\hline Very good & 24 & 24.0 \\
\hline Good & 58 & 58.0 \\
\hline Dissatisfied & 14 & 14.0 \\
\hline Total & 100 & 100.0 \\
\hline
\end{tabular}

From Table-1, one could see that $14 \%$ of the employees are dissatisfied with the medical facilities provided by the management. The $95 \%$ confidence interval for this event is $(0.0720,0.2080)$. 
If the organization takes necessary measures to address the grievances of the employees, then this percentage may come down to $7 \%$ and may go up to $20 \%$ in future if they do not address their problems. It is very important for the management to ensure that the percentage will come down below $7 \%$ in future [16]-[18].

The study reveals that there is a positive correlation among the satisfaction rates and the implementation of various employee safety and welfare initiatives, which should be properly enforced to strengthen in order to increase employee satisfaction, which in effect can lead to increased productivity. An employee can feel safe in the organization to be happy with his employment. Employee welfare ensures health and safety, comfort and efficiency of the workers,in turn to have a positive impact on employee productivity in the organization. $\square$ Company must provide smoking zone for the employee regarding safety in organization[19]-[21].

For employees, the organization needs to conduct more security training programs. Need to provide safety equipment where necessary and oversee the employees to follow safety measures.

Organization should implement safety in entrance gates with $\mathrm{CC}$ cameras installation, bomb detector equipment and electricity fencing around water canals.

Organization should provide separate rest rooms and wash rooms for each department for both male and female employees. $\square$ Organization should provide drinking water facilities near the plant or outside of plant for working labour as well as employees[22]-[25].

\section{CONCLUSION}

Each industry sector is diverse and the policies and practices of individuals are unique for the sectors. It is asset-intensive and engineering-driven when considering the power industry. Ironically, people in the power industry are usually loyal to the business for a long time, and this dedication goes on for decades.

\section{REFERENCES}

1) Vasanthi, S. \& Rabiyathul Basariya, S. 2019, "Influence of value analysis and cross training in industry", International Journal of Engineering and Advanced Technology, vol. 8, no. 6, pp. 1810-1811.

2) Velvizhi, R., Sri Gowtham, S. \& Jeya Priya, D. 2019, "Examination of early feedbacks for effective product retailing on E-commerce websites", International Journal of Engineering and Advanced Technology, vol. 8, no. 6 Special Issue 2, pp. 703-706.

3) Anuradha, C., Pothumani, S. \& Kavitha, R. 2019, "A novel method towards E-commerce", International Journal of Engineering and Advanced Technology, vol. 8, no. 6 Special Issue 2, pp. 535-538.

4) Thomas, J. \& Rabiyathul Basariya, S. 2019, "A study on the issues of financial ratio analysis", Indian Journal of Public Health Research and Development, vol. 10, no. 3, pp. 1079-1081.

5) Ramachandran, S. \& Rabiyathul Basariya, S. 2019, "Online marketing study on customer satisfaction and relationship", Indian Journal of Public Health Research and Development, vol. 10, no. 3, pp. 1072-1078.

6) Priya, R., Vinothini, G. \& Cor Jesu, C.D. 2019, "The mentor-protégé relationship for professional growth", Journal of Advanced Research in Dynamical and Control Systems, vol. 11, no. 9 Special Issue, pp. 1110-1119.

7) Jannifer Rani, N., Bina Pani, S. \& Nimisha, N.S. 2019, "A study on money back polices available in LIC", Journal of Advanced Research in
Dynamical and Control Systems, vol. 11, no. 9 Special Issue, pp. 833-839.

8) Saillaja, V., Jhansi Rani, K. \& Catherine, R. 2019, "Global marketing management planning and organization", Journal of Advanced Research in Dynamical and Control Systems, vol. 11, no. 9 Special Issue, pp. 489-493.

9) Saillaja, V., Jhansi Rani, K. \& Catherine, R. 2019, "The new phase of marketing information system", Journal of Advanced Research in Dynamical and Control Systems, vol. 11, no. 9 Special Issue, pp. 482-488.

10) Thoufiqulla \& Raju, D.V. 2019, "Perception of indian investor towards investment in mutual funds with special reference to mip funds", Journal of Advanced Research in Dynamical and Control Systems, vol. 11, no. 5, pp. 177-183.

11) Jasmine, K.R.M. \& Basariya, S.R. 2018, "A study on the customers benefits on mutual funds", International Journal of Civil Engineering and Technology, vol. 9, no. 4, pp. 45-48.

12) Vasanthi, S. \& Basariya, S.R. 2019, "Pros and cons of on the job training versus off the job training", International Journal of Scientific and Technology Research, vol. 8, no. 10, pp. 671-674.

13) Pavithra, J. \& Ganesan, M. 2016, "A study on awareness and impact of micro-financial schemes", International Journal of Applied Business and Economic Research, vol. 14, no. 8, pp. 5449-5460.

14) Pavithra, J., Dilli Babu, P. \& Ambuli, T.V. 2014, "A study on budgetary control at Maruti Service Masters, Chennai", International Journal of Applied Business and Economic Research, vol. 12, no. 2, pp. 151-161.

15) Gunaraja, T.M. \& Venkatrama Raju, D. 2018, "Determining factors of organisational climate with reference to leadership styles", International Journal of Mechanical Engineering and Technology, vol. 9, no. 9, pp. 1327-1332.

16) Gunaraja, T.M. \& Venkatrama Raju, D. 2018, "The role of job satisfaction and training of employees in determining organisational climate of a selected industry", International Journal of Civil Engineering and Technology, vol. 9, no. 8, pp. 1266-1269.

17) Aarathy, T.S. \& Raju, D.V. 2018, "Performance appraisal and its effects on employees with respect to it sector in Chennai city", International Journal of Civil Engineering and Technology, vol. 9, no. 6, pp. 1535-1538.

18) Aarathy, T.S. \& Raju, D.V. 2018, "Employee perception towards performance appraisal system in IT sector", International Journal of Mechanical Engineering and Technology, vol. 9, no. 5, pp. 131-135.

19) Porselvi, W., Jublee, D. \& Sivanesan, G. 2018, "A study on factors influencing adoption of technology and innovation in banking industry, tamilnadu, India", International Journal of Mechanical Engineering and Technology, vol. 9, no. 5, pp. 789-800.

20) Akessa, G.M. and Dhufera, A.G., 2015. Factors That Influences Students Academic Performance: A Case of Rift Valley University, Jimma, Ethiopia. Journal of Education and Practice, 6(22), pp.55-63.

21) Miller, G. and Shih, C.C., 1999. A faculty assessment of the academic rigor of on-and off-campus courses in agriculture. Journal of Agricultural Education, 40, pp.57-65.

22) Tsinidou, M., Gerogiannis, V. and Fitsilis, P., 2010. Evaluation of the factors that determine quality in higher education: an empirical study. Quality Assurance in education, 18(3), pp.227-244.

23) Farooq, M.S., Chaudhry, A.H., Shafiq, M. and Berhanu, G., 2011 Factors affecting students' quality of academic performance: a case of secondary school level. Journal of quality and technology management, 7(2), pp.1-14.

24) Fitsilis, P., Gerogiannis, V. and Anthopoulos, L., 2014. Ontologies for software project management: a review. Journal of Software Engineering and Applications, 7(13), p.1096.

25) Adams, J.D. and Jaffe, A.B., 1996. Bounding the effects of R\&D: an investigation using matched establishment-firm data(No. w5544). National bureau of economic research.

\section{AUTHORS PROFILE}

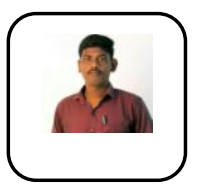

K. Thiyagarajan Assistant Professor, Department of Science and Humanities, Bharath Institute of Higher Education and Research, Chennai, India. 
S. Jeni Theresa Assistant Professor, Department of Science and Humanities, Bharath Institute of Higher Education and Research, Chennai, India.

T. Subhalatha Assistant Professor, Department of Science and Humanities, Bharath Institute of Higher Education and Research, Chennai, India. 